九州大学学術情報リポジトリ

Kyushu University Institutional Repository

Effects of Long term Exposure to Atmospheric Carbon Dioxide Enrichment on Flowering and Podding in Soybean

Nakamoto, Hiroaki

Laboratory of Crop Science, Division of Agricultural Botany, Department of Plant Resources, Graduate School of Bioresource and Bioenvironmental Sciences, Kyushu University

Zheng, Shao-Hui

Laboratory of Crop Science, Division of Agricultural Botany, Department of Plant Resources, Faculty of Agriculture, Kyushu University

Furuya, Tadahiko

Laboratory of Crop Science, Division of Agricultural Botany, Department of Plant Resources, Faculty of Agriculture, Kyushu University

Tanaka, Kaname

Agricultural Electnfication Testing Center, Kyushu Eiectric Power Co., Inc.

他

https://doi.org/10.5109/24418

出版情報 : 九州大学大学院農学研究院紀要. 46 (1)，pp.23-29，2001-10-30. Kyushu University バージョン：

権利関係 : 
J. Fac. Agr., Kyushu Univ., 46 (1), 23-29 (2001)

\title{
Effects of Long term Exposure to Atmospheric Carbon Dioxide Enrichment on Flowering and Podding in Soybean
}

\author{
Hiroaki NAKAMOTO*, Shao-Hui ZHENG, Tadahiko FURUYA, \\ Kaname TANAKA**, Akira YAMAZAKI** \\ and Masataka FUKUYAMA***
}

\author{
Laboratory of Crop Science, Division of Agricultural Botany, Department of Plant Resources, \\ Faculty of Agriculture, Kyushu University, Fukuoka 812-8581, Japan \\ (Received May 16, 2001 and accepted July 11, 2001)
}

\begin{abstract}
It is known that increasing atmospheric carbon dioxide $\left(\mathrm{CO}_{2}\right)$ concentration resulted in the enhancement of vegetative growth and an increase in seed yield in Soybean (Glycine max (L.) Merrill). However, the way this increase in seed yield comes about is not well known. The objective of this study was to make clear the effects of $\mathrm{CO}_{2}$ enrichment on flowering and podding, since these are the factors which directly limit the seed yield in soybean. Cultivar 'Fukuyutaka' were grown in the ambient $\mathrm{CO}_{2}$ concentration ( $\mathrm{AC}: 350 \mu \mathrm{mol} \mathrm{CO}_{2} \mathrm{~mol}^{-1} \mathrm{Air}$ ) and an enriched $\mathrm{CO}_{2}$ concentration (EC: $700 \mu \mathrm{mol} \mathrm{CO}_{2} \mathrm{~mol}^{-1} \mathrm{Air}$ ) throughout the growth period. The effects of $\mathrm{EC}$ on the flowering were significantly different among the individual racemes. On the terminal racemes and the primary racemes, there was no difference in the total number of flowers between $\mathrm{AC}$ and $\mathrm{EC}$, although the number of flowers at the peak of flowering differed slightly with the $\mathrm{CO}_{2}$ regime used. On the secondary racemes with compound leaves, EC condition increased the number of flowers compared with $\mathrm{AC}$. The opposite effect was seen on the secondary racemes without compound leaves. Furthermore, large number of flowers on the tertiary racemes appeared in EC throughout the flowering period. The number of pods and the pod-setting ratio in EC condition on the secondary racemes, the secondary racemes with compound leaves and the tertiary racemes were larger than those in $\mathrm{AC}$ condition. Therefore, enrichment of $\mathrm{CO}_{2}$ increased seed yield because of the increase in the number of flowers and the high pod-setting ratio on the high order racemes (the secondary racemes, the secondary racemes with compound leaves and the tertiary racemes), which appeared at later time during the flowering period.
\end{abstract}

\section{INTRODUCTION}

Since the Industrial Revolution, atmospheric carbon dioxide $\left(\mathrm{CO}_{2}\right)$ concentration has been increasing. This increase is almost certainly due mainly to the continued burning of fossil fuels. According to the IPCC (1995), the atmospheric $\mathrm{CO}_{2}$ concentration is predicted to double by the end of this century. The steady increasing level of $\mathrm{CO}_{2}$ is expected to enhance plant growth and to increase seed yield in grain crops. Kimball (1983) reported that vegetative growth was enhanced significantly by doubling the atmospheric $\mathrm{CO}_{2}$ concentration. Longer term experiments have generally shown that

* Laboratory of Crop Science, Division of Agricultural Botany, Department of Plant Resources, Graduate School of Bioresource and Bioenvironmental Sciences, Kyushu University, Fukuoka 812-8581, Japan

** Agricultural Electrification Testing Center, Kyushu Electric Power Co., Inc. 1-10-1, Takagise-higashi, Saga 849-0922, Japan

*** Corresponding author (E-mail: fukuyama@agr.kyushu-u.ac.jp) 
enriched $\mathrm{CO}_{2}$ concentration have brought about high photosynthetic rates, rapid rates of biomass accumulation, and therefore high yields (Kimball, 1983; Zelitch, 1982). However, the morphological developmental process by which this increase in seed yield come about is not well known.

Flower and pod shedding are the limiting factors for seed yield in soybean. This might be because of the overlap of vegetative and reproductive growth, namely nutrient competition between both growths. Therefore, an investigation of the number of flowers and the pod-setting ratio on individual raceme orders is considered to be an effective way of estimating the effect of enhanced $\mathrm{CO}_{2}$ concentration (EC) on seed yield in soybean. Some preliminary data on planting date and planting density illustrated that the total number of flowers and the change in the number of flowers opening each day on each raceme order also different among cultivars (Kuroda et al, 1992; Fujita, 1995).

The objective of this study was to determine the effects of $\mathrm{CO}_{2}$ enrichment on flowering and podding, in order to clarify whether and how could $\mathrm{CO}_{2}$ enrichment increase the seed yield in soybean.

\section{MATERIALS AND METHODS}

Soybean (Glycine $\max (\mathrm{L}$.) Merrill cv. Fukuyutaka, maturity type Nc) seeds were inoculated with Bradyrhizobium japonicum and planted in plastic pots $(20 \mathrm{~cm}$ diameter by $20 \mathrm{~cm}$ in height) filled with fine sand on $19 \mathrm{July}, 2000$ in the institute of Agricultural Electrification Testing Center of Kyushu Electric Power Co., Inc. at Saga (Long. $130^{\circ} 34^{\prime}$ E, Lat. $33^{\circ} 27^{\prime} \mathrm{N}$ ). After emergence, plants were moved into the natural light growth chambers where the $\mathrm{CO}_{2}$ concentrations were maintained at $350 \mu \mathrm{mol} \mathrm{CO}_{2} \mathrm{~mol}^{-1}$ Air (Ambient $\mathrm{CO}_{2}$ concentration (AC)) and $700 \mu \mathrm{mol} \mathrm{CO} \mathrm{mol}^{-1}$ Air (enriched $\mathrm{CO}_{2}$ concentration (EC)). Day/night air temperatures were controlled at about $28 / 22^{\circ} \mathrm{C}$, except at $25^{\circ} \mathrm{C}$ for 2 hours during sunrise (from 7:00 to 9:00) and sunset (from 18:00 to 20:00). Nutrient solution (Table 1) was given every day for 5 minutes at $9: 00$ and 14:00 by an automatic watering system. After flowering started on 26 August, the date and raceme position of flowers that had opened that day were recorded in both treatments every 2 days on a small label $8 \mathrm{~mm}$ in width and $21 \mathrm{~mm}$ in length. The labels were then wrapped around the pedicel of

Table 1. Conposition of nutrient solution

\begin{tabular}{cc}
\hline Nutrient & Concentration (ppm) \\
\hline $\mathrm{N}$ & 88.5 \\
$\mathrm{P}_{2} \mathrm{O}_{5}$ & 69.0 \\
$\mathrm{~K}_{2} \mathrm{O}$ & 110.3 \\
$\mathrm{CaO}$ & 89.7 \\
$\mathrm{MgO}$ & 35.2 \\
$\mathrm{Fe}$ & 2.90 \\
$\mathrm{Zn}$ & 0.04 \\
$\mathrm{Cu}$ & 0.02 \\
$\mathrm{~B}$ & 1.00 \\
$\mathrm{Mo}$ & 0.02 \\
$\mathrm{Mn}$ & 1.00 \\
\hline
\end{tabular}


flowers. Flowers were distinguished at each node and each raceme order according to Torigoe et al (1982) as follows,

Terminal racemes - formed at the top of main stem and branches.

Primary racemes - formed at the leaf axils of main stem and branches directly.

Secondary racemes - formed at both sides of the primary racemes axils.

Secondary racemes with compound leaves - formed at the same position as the secondary racemes with a few nodes like branches.

Tertiary racemes - formed at both sides of the secondary racemes and the secondary racemes with compound leaves. The racemes which start flowering after the tertiary racemes were included as the tertiary raceme.

The investigation continued until 23 September when the flowering was almost finished. Matured plants were harvested on 17 November. The vegetative growth, yield components and seed yield were measured after being dried naturally in a room. Six plants were investigated in each chamber.

\section{RESULTS}

Fig. 1 shows the change in the total number of flowers affected by $\mathrm{CO}_{2}$ enrichment. From 0 to 16 days after flowering (DAF), the change in the number of flowers opening daily under enriched $\mathrm{CO}_{2}$ concentration (EC) was almost the same as that under ambient $\mathrm{CO}_{2}$ concentration $(\mathrm{AC})$. However, from $16 \mathrm{DAF}$, more flowers opened under EC condition. By the end of flowering therefore, the total number of flowers in EC were significantly greater than that in $\mathrm{AC}$ at the end of flowering.

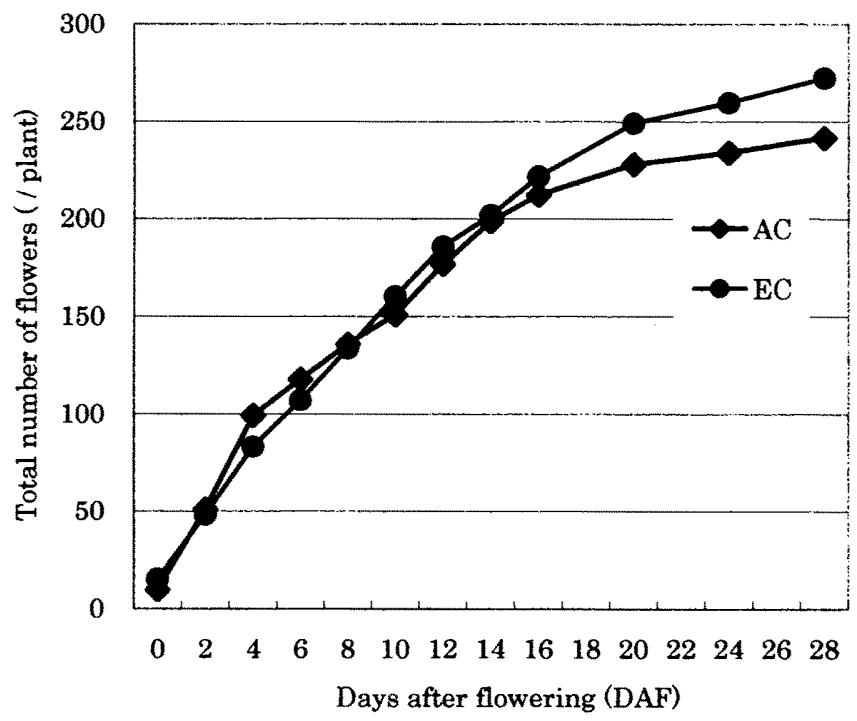

Fig. 1. Changes in flowering pattern of the total number of flowers AC: $350 \mu \mathrm{mol} \mathrm{CO}_{2} \mathrm{~mol}^{\prime} \quad$ EC: $700 \mu \mathrm{mol} \mathrm{CO}_{2} \mathrm{~mol}^{-1}$ 
Fig. 2 shows the change in the number of daily opened flowers on individual order racemes. In both $\mathrm{EC}$ and $\mathrm{AC}$, the flowering started on the primary racemes. It was followed by the terminal racemes after 2 days, the secondary raceme with compound leaves after 6 days, the secondary racemes after 8 days, and finally the tertiary racemes after 14 days. The peaks in the number of daily opened flowers on the primary and the terminal racemes were broad in EC but sharp in AC. Under EC condition, there was a slight decrease in the number of flowers opening each day on the secondary racemes, and an increase on the secondary racemes with compound leaves. On the tertiary racemes, the number of flowers opening each day was always greater in EC than in AC.

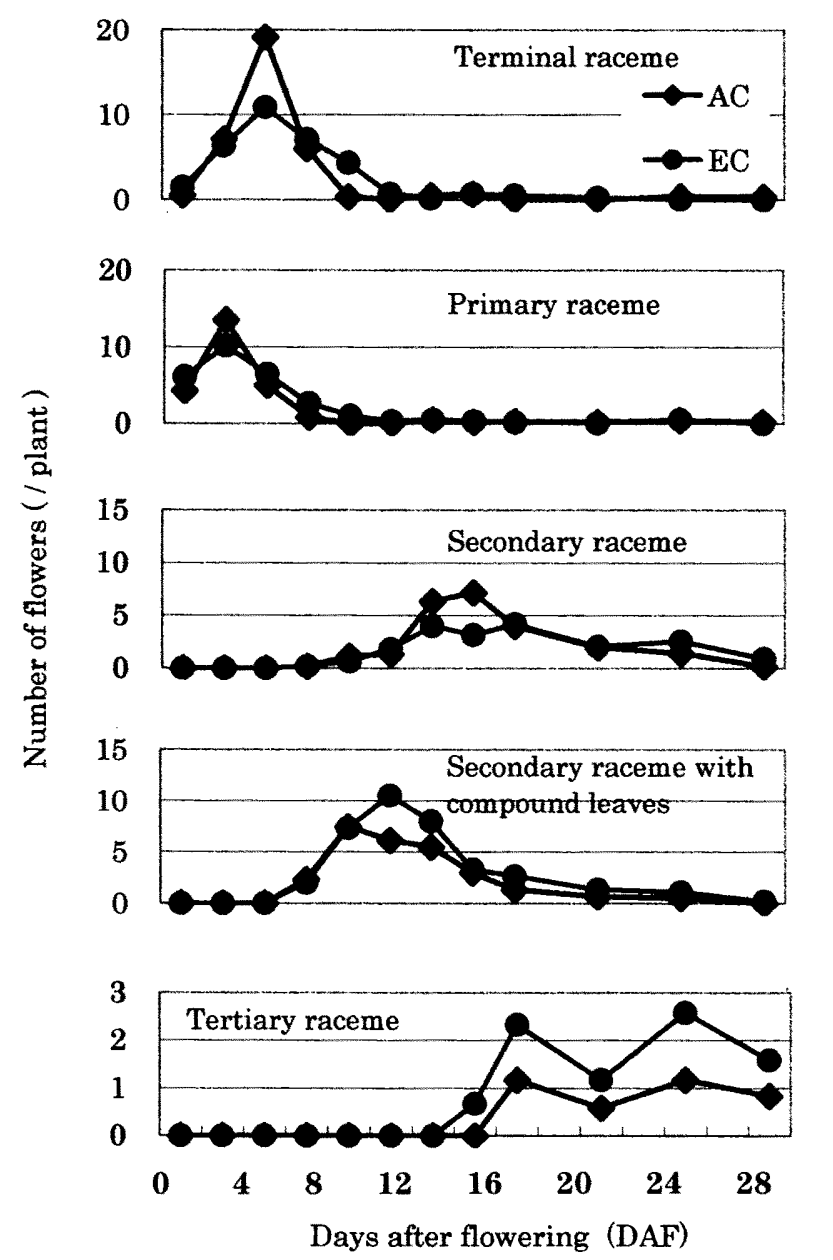

Fig. 2. Changes in flowering pattern of the number of daily flowers on the individual racemes.

AC: $350 \mu \mathrm{mol} \mathrm{CO}_{2} \mathrm{~mol}^{-1} \quad$ EC: $700 \mu \mathrm{mol} \mathrm{CO}_{2} \mathrm{~mol}^{-1}$ 
The number of flowers, pods and pod-setting ratio on the individual raceme orders are shown on Table 2. There were no significant differences in the number of flowers on the primary and the terminal racemes between $\mathrm{AC}$ and $\mathrm{EC}$. In EC, there were less flowers on the secondary racemes and significantly more on the secondary racemes with compound leaves and the tertiary racemes. Therefore, the increase in the total number of flowers in EC was contributed by the increase in the number of flowers on the high order racemes (consisting of the secondary racemes, the secondary racemes with compound leaves and the tertiary racemes). The number of pods on the terminal and the primary

Table 2. Effects of $\mathrm{CO}_{2}$ enrichment on the number of flowers, pods and pod-setting ratio on individual racemes per plant in $350 \mu \mathrm{mol} \mathrm{CO} \mathrm{mol}^{-1}(\mathrm{AC})$ and $700 \mu \mathrm{mol} \mathrm{CO} \mathrm{mol}^{-1}$ (EC) after harvest

\begin{tabular}{|c|c|c|c|c|c|c|}
\hline & \multicolumn{3}{|c|}{$350 \mu \mathrm{mol} \mathrm{CO} \mathrm{mol}^{-1}(\mathrm{AC})$} & \multicolumn{3}{|c|}{$700 \mu \mathrm{mol} \mathrm{CO}_{2} \mathrm{~mol}^{-1}(\mathrm{EC})$} \\
\hline & number of flowers & number of pods & $\mathrm{PR}^{*}(\%)$ & number of flowers & number of pods & $\operatorname{PR}(\%)$ \\
\hline terminal raceme & $73.3 \pm 5.51(29.8)$ & $45.7 \pm 6.03 \quad(24.0)$ & 62.3 & $69.7 \pm 9.07(23.7)$ & $27.7 \pm 11.80(13.2)$ & 39.7 \\
\hline primary raceme & $52.3 \pm 3.51(21.3)$ & $45.3 \pm 4.62$ & 86.6 & $52.7 \pm 7.09(17.9)$ & $28.0 \pm 11.85(13.3)$ & 53.2 \\
\hline secondary raceme & $55.7 \pm 3.21(22.7)$ & $47.0 \pm 4.58 \quad(24.6)$ & 84.4 & $44.0 \pm 7.21(14.9)$ & $40.0 \pm 4.00 \quad(19.1)$ & 90.9 \\
\hline $\begin{array}{l}\text { secondary raceme with } \\
\text { compound leaves }\end{array}$ & $47.3 \pm 5.69(19.2)$ & $41.3 \pm 6.66 \quad(21.7)$ & 87.3 & $81.7 \pm 4.73(27.7)$ & $75.0+9.64 \quad(35.8)$ & 91.8 \\
\hline tertiary raceme & $17.3 \pm 8.62(7.0)$ & $11.3 \pm 5.51$ & 65.4 & $46.7 \pm 20.53(15.8)$ & $39.0 \pm 23.07(18.6)$ & 83.6 \\
\hline lower order raceme & $125.7 \pm 4.73(51.1)$ & $91.0 \pm 7.94 \quad(47.7)$ & 72.4 & $122.3 \pm 15.00(41.5)$ & $55.7 \pm 19.22(26.6)$ & 45.5 \\
\hline high order raceme & $120.3 \pm 7.23(48.9)$ & $99.7 \pm 5.51 \quad(52.3)$ & 82.8 & $172.3 \pm 22.81(58.5)$ & $154.0 \pm 26.21(73.4)$ & 89.4 \\
\hline total & $246.0 \pm 3.0(100.0)$ & $190.7 \pm 12.50(100.0)$ & 77.5 & $294.7 \pm 9.45(100.0)$ & $209.7 \pm 25.02(100.0)$ & 71.2 \\
\hline $\begin{array}{l}\text { *: Pod-setting } x \\
\text { Values in }() \\
\text { The lower or } \\
\text { The high ord } \\
\text { tertiary racer }\end{array}$ & $\begin{array}{l}\text { ratio } \\
\text { are relative value } \\
\text { der racemes inclu } \\
\text { er racemes incluo } \\
\text { mes. }\end{array}$ & de the secondary, & and th & $\begin{array}{l}\text { rs of the total. ( } \\
\text { rimary racemes. } \\
\text { ndary with conp }\end{array}$ & ound leaves ar & \\
\hline
\end{tabular}

Table 3. Vagetative growth, yield components and yield per plant in both treatments after harvest

\begin{tabular}{|c|c|c|}
\hline & $\begin{array}{c}350 \mu \mathrm{mol} \mathrm{CO}_{2} \mathrm{~mol}^{-1} \\
\text { (AC) }\end{array}$ & $\begin{array}{c}700 \mu \mathrm{mol} \mathrm{CO}_{2} \mathrm{~mol}^{-1} \\
(\mathrm{EC})\end{array}$ \\
\hline Main stem length (cm) & $70.7 \pm 4.1(100)$ & $69.8 \pm 4.4 \quad(98.8)$ \\
\hline Number of nodes on main & $13.5 \pm 0.8(100)$ & $13.8 \pm 0.4(102.5)$ \\
\hline Total number of nodes & $69.8 \pm 7.1(100)$ & $82.0 \pm 10.4(117.4)$ \\
\hline Number of branches & $11.2 \pm 1.3(100)$ & $12.0 \pm 2.5(107.5)$ \\
\hline Number of filled pods & $168.7 \pm 25.9(100)$ & $192.5 \pm 34.3(114.1)$ \\
\hline Number of filled seeds & $323.7 \pm 27.1(100)$ & $351.8 \pm 76.4(108.7)$ \\
\hline Stem dry weight (g) & $19.6 \pm 4.5(100)$ & $25.3 \pm 6.0(129.1)$ \\
\hline Seeds yield $(\mathrm{g})$ & $101.9 \pm 19.6(100)$ & $114.9 \pm 29.6(112.8)$ \\
\hline Weight per 100 seed $(\mathrm{g})$ & $31.3 \pm 3.8(100)$ & $32.5 \pm 2.7(104.1)$ \\
\hline
\end{tabular}

Values in ( ) are relative values as against $\mathrm{AC} .(\mathrm{n}=6)$. 
racemes were smaller in $\mathrm{EC}$ than in $\mathrm{AC}$, while the number on the secondary racemes in $\mathrm{EC}$ was almost the same as in AC. On the secondary racemes with compound leaves and the tertiary racemes were greater in EC than in AC. Hence, the pod-setting ratio under $\mathrm{EC}$ was lower on the terminal and the primary racemes but was higher on the other racemes compared with those in $\mathrm{AC}$.

Vegetative growth, yield components and seed yield after harvest are shown in Table 3. Significant increases were observed in the total number of nodes, stem dry weight, the number of matured pods and seeds in EC. As a result, seed yield per plant was about $13 \%$ higher in $\mathrm{EC}$ than in $\mathrm{AC}$, but there was no significant difference in seed size between $\mathrm{AC}$ and $\mathrm{EC}$. Therefore, $\mathrm{CO}_{2}$ enrichment increased the number of matured pods by increasing the number of flowers and causing a high pod-setting ratio on the high order racemes compared with those in $\mathrm{AC}$.

\section{DISCUSSION}

It was revealed in this study that enriched of $\mathrm{CO}_{2}$ increased seed yield because of the increase in the number of flowers and the high pod-setting ratio on the high order racemes (the secondary racemes, the secondary racemes with compound leaves and the tertiary racemes), which appeared at later time in the flowering period. An increase of $30 \%$ in stem dry weight and $13 \%$ in seed weight with $\mathrm{CO}_{2}$ enrichment seemed to be lower than that reported by Allen et al (1987). One major factor could be the approximately $40 \%$ shading by two layers of vinyl in the roof of our chambers, so that the vegetative growth was not too much affected by EC.

The remarkable result of this study is that $\mathrm{CO}_{2}$ enrichment caused a low pod-setting ratio on lower order raceme (the terminal and the primary racemes). Yoshida et al (1983) classified flowers by DAF and found that the flowers which opened from 0 to 10 $\mathrm{DAF}$ in determinate type and from 0 to $15 \mathrm{DAF}$ in inter- or indeterminate types are important for pod set and seed yield. Moreover, it was also important for seed yield to maintain high pod-setting ratio on the lower order racemes (Isobe et al, 1995; Yoshida et al, 1983). In this study, the pod-setting ratio derived from the lower order racemes was $46 \%$ in EC, which is relatively lower than any other reports (Fujita, 1995; Kuroda et al, 1992; Yoshida et al, 1983). Those results could be caused by either the difference in cultivar, or the distributive competition of assimilates between vegetative and reproductive organs. However, further experiments are needed to clarify this, such as investigating the change in flowering patterns and the number of flowers on the individual raceme orders when plant is exposed to enriched $\mathrm{CO}_{2}$ during different growth periods.

\section{REFERENCES}

Allen, L. H. Jr., J. K. Boote, J. W. Jones, P. H. Jones, R. R. Valle, B. Acock, H. H. Rogers and R. C. Dahlman 1987 Response of vegetation to rising carbon dioxide: photosynthesis, biomass and yield of soybean. Global Biogeochem. Cycles, 1: 1-14

Fujita, K. 1995 Effects of seeding times on flowering and seed setting habits with reference to raceme order in soybean cv. "Tachinagaha" and "Akishirome". Bull. Kagawa Agric. Exp. Sta., 46: 77-78

Isobe, K., M. Kokubun and Y. Tsuboki 1995 Effects of soybean raceme-order on pod set and seed growth in three cultivars. Jpn. J. Crop Sci, 64: 281-287

IPCC. 1995 Second assessment climate change. IPCC, Geneva, pp. 1-73 
Kimball, B. A. 1983 Carbon dioxide and agricultural yield: assemblage and analysis of 430 prior observations. Agron. J., 75: 779-788

Kuroda, T., K. Kohri and S. Kumano 1992 Influence of planting density to podding of soybean plants with special reference to raceme order. Jpn. J. Crop Sci., 61: 426-432

Matsunaga, R. S. Matsumoto, I. Shimano and S. Shimada 1983 Varietal differences in nitrogen response of soybeans associated with their nodulation. Jpn. J. Crop Sci., 52: 423-429

Torigoe, Y., H. Shinshi, and H. Kurihara 1982 Studies on developmental morphology and yield determining process of soybeans II. Developmental regularity of flower clusters and flowering habit from a viewpoint of gross morphology. Jpn. J. Crop Sci., 51: 89-96

Yoshida, K., F. Nomura and K. Gotoh 1983 Significance of intra-plant flowering date in soybean seed production. 2. Number of flowers, podding efficiency, nodal distribution of pods and yield components among different flowering dates. Jpn. J. Crop Sci., 52: 567-573

Zelitch, I. 1982 The close relationship between net photosynthesis and crop yield. Bioscience, 32: 796-802 